\title{
KEBERADAAN PEMEGANG SAHAM DALAM RUPS DENGAN SISTEM TELECONFERENCE TERKAIT JARINGAN BERMASALAH DALAM PERSPEKTIF CYBER LAW
}

\section{Oleh: \\ Ni Ketut Supasti Dharmawan, Putu Tuni Cakabawa Landra, Ni Putu Purwanti²}

\section{ABSTRACT}

In Indonesia, the General meeting of Shareholder through teleconference mechanism can be conducted under the provision of Article 77 of Law No. 40 of 2007 concerning Limited Liability Company. This teleconferencing mechanism allows all participants to see and to hear each other as well as to participate in the teleconference meeting.

There is legal vacuum with regard to position of shareholders in the General Meeting by teleconference mechanism, especially in the case of network problems. However, by analogy with the legal construct of the provisions of Article 90 of the Company Law can be stated that the position of shareholders continues to be recognized as a legal subject who has legal right and has valid votes counted even if the minutes of the meeting have not been signed electronically because internet network problem as long as treatise or the minute of General Meeting of shareholders is made by notarial deed and shall be signed by the Notary who made the deed.

Key Words: General Meeting of Sharholders, Teleconference, System down, the Law No. 40 of 2007.

\section{PENDAHULUAN}

\subsection{Latar Belakang}

Teknologi komunikasi berkembang sangat pesat dan menggelobal di seluruh dunia termasuk di Indonesia. Dunia tanpa

Karya ilmiah ini merupakan hasil penelitian yang di biayai dari dana Dipa BLU Program Studi Magister (S2) Ilmu Hukum PPS UNUD dengan SK Rektor nomor 2113/UN.14.4/HK./2014, telah di presentasikan dalam seminar di Program Magister (S2) Ilmu Hukum pada tanggal 31 Oktober. 2014

Penulis kesatu dan kedua adalah dosen pada Program Studi Magister (S2) Ilmu Hukum Program Pascasarjana UNUD serta penulis kesatu, penulis kedua dan penulis ketiga dosen pada FH UNUD., e-mail : arasswk@ yahoo.com batas, "borderless world", begitu sering dikemukakan untuk menggambarkan betapa cepat dan pesatnya teknologi itu berkembang serta memainkan peranan yang sangat penting terutama dalam teknologi komunikasi seperti: menjadi penghubung antar individu, kelompok komunitas juga korporasi dalam waktu yang amat cepat dan spektakuler tanpa harus menghadirkan pihakpihak yang berkomunikasi hadir berhadapan secara face to face.

Peran penting perkembangan teknologi informasi dalam bidang korporasi tidak dapat dipungkiri pada gilirannya membawa 
konsekuensi berkaitan dengan aspek-aspek hukum yang melingkupinya. Di Indonesia, dalam kegiatan berbisnis para pelaku bisnis membuka dan menjalankan bisnis mereka dengan berbagai bentuk-bentuk badan hukum salahsatuyangmenjadipilihanpalingdominan adalah berbentuk badan hukum Perseroan Terbatas (Perseroan). Dalam konteks ini, perkembangan teknologi memainkan peran penting pendirian perseroan di berbagai daerah di Indonesia saling memberikan keuntungan dan kemudahan terhadap satu sama lain. Kemajuan teknologi tersebut memudahkan kegiatan-kegiatan dan organorgan yang berada dalam suatu perseroan berkomunikasi dan berinteraksi secara lebih efisien, cepat dan hemat. Oleh karena itu, komunikasi maupun proses kegiatan yang terjadi dalam suatu perseroan tidak hanya lagi berbasiskan sistem konvensional dengan tatap muka langsung dan di atas kertas saja, namun sudah melampau batas-batas wilayah bahkan negara dengan memanfaatkan kecanggihan teknologi informasi. Di Indonesia pemanfaatan sarana teknologi untuk kepentingan pengembangan bisnis sudah diakomodir pelaksanaannya oleh beberapa peraturan perundang-undangan.

Dalam kehidupan sehari-hari, kegitan dengan menggunakan transaksi elektronik sebagai akibat dari pesatnya perkembangan teknologi banyak dipergunakan baik oleh masyarakat di Indonesia dengan masyarakat Indonesia di wilayah lainnya maupun hingga manca negara. Beralihnya transaksi konvensional dengan media kertas menjadi transaksi yang menggunakan sistem elektronik adalah suatu fakta ${ }^{3}$ yang sesuai dengan rekomendasi yang sejak lama telah diberikan dalam kesepakatan global dalam forum UNCITRAL (United Nation Commission on International Trade Law) mengenai perlunya pengakuan nilai hukum pada suatu informasi dan/atau dokumen elektronik $^{4}$.

Undang-Undang No. 40 Tahun 2007 tentang Perseroan Terbatas (UUPT) sebgaai pengganti ketentuan sebelumnya berisi penyempurnaan dan pembaharuan yang bersifat aspiratif, mengandung keadilan dan kebenaran yang mementingkan kepantingan rakyat dalam acuan Negara Kesatuan Republik Indonesia. ${ }^{5}$ Diperbaruinya pengaturan mengenai perseroan hingga menjadi UUPT tidak terlepas dari tujuan peningkatan peran perseroan dalam pembangunan nasional dan landasan yang kuat bagi dunia usaha yang ingin dicapai dalam pesatnya perkembangan ekonomi di era globalisasi ini. ${ }^{6}$ UUPT adalah salah satu undang-undang yang mengakomodir pesatnya kemajuan teknologi informasi yang salah satunya adalah dimungkinkannya teleconference sebagai salah satu tata cara untuk menyelenggarakan Rapat Umum Pemegang Saham (RUPS). Dalam menghadiri RUPS, pemegang saham dapat datang sendiri maupun diwakilkan dengan

Edmon Makarim, 2012, Notaris \& Transaksi Elektronik (Kajian Hukum tentang Cybernotary atau Electronic Notary), PT. Rajagrafindo Persada, Jakarta, h. 1.

Ibid.

Jamin Ginting, 2007, Hukum Perseroan Terbatas (UU No. 40 Tahun 2007), PT Citra Aditya Bakti, Bandung, h. v.

$6 \quad$ Ibid. 
berdasarkan surat kuasa dan kemudian menggunakan hak suaranya sesuai dengan jumlah saham yang dimilikinya. ${ }^{7}$

Dalam UUPT, pengaturan mengenai tempat diadakannya atau diselenggarakannya RUPS dapat ditemukan dalam ketentuan Pasal 76 dan Pasal 77. RUPS dalam suatu perseroan tidak hanya dapat dilakukan secara konvensional dimana seluruh pemegang saham harus berkumpul di suatu tempat dalam wilayah negara Republik Indonesia dan bertatap muka satu sama lain tetapi kini juga dapat dilakukan dengan media telekonferensi, video konferensi, atau sarana media elektronik lainnya yang memungkinkan semua peserta RUPS saling melihat dan mendengar secara langsung serta berpartisipasi dalam rapat (Pasal 77 ayat 1 UUPT). Secara singkat, RUPS dapat dilakukan dengan online system.

Berdasarkan ketentuan Pasal 77 (1) UUPT diketahui bahwa penyelenggaraan RUPS selain dilakukan sesuai pada umumnya sebagaimana diatur dalam Pasal76, RUPS dapat juga dilakukan melalui media telekonferensi, video konferensi, atau sarana media elektronik lainnya yang memungkinkan semua peserta RUPS saling melihat dan mendengar secara langsung serta berpartisipasi dalam rapat meskipun tidak hadir berhadap-hadapan dalam suatu tempat pertemuan.

Berkaitan dengan penyelenggaraan RUPS dengan cara non-konvensional tersebut, sesuai dengan Pasal 5 ayat (1)

Ibid, h. 106.
Undang-Undang Nomor 11 Tahun 2008 tentang Informasi dan Transaksi Elektronik (UUITE) ditentukan bahwa informasi elektronik dan/atau dokumen elektronik dan/atau hasil cetakannya merupakan alat bukti hukum yang sah, yang juga diatur dalam Peraturan Pemerintah No. 82 Tahun 2012 tentang Penyelenggaraan Sistem dan Transaksi Elektronik (PP 82/2012) yang merupakan peraturan pemerintah sebagai pelaksanaan beberapa pasal dari UUITE. Secara normatif, RUPS dengan mekanisme teleconference memang dimungkinkan berdasarkanketentuantersebutdiatas. Namun dalam realinya muncul permasalahan, ketika RUPS dengan mekanisme teleconference sedang berlangsung acapkali terjadi jaringan internet bermasalah atau system down, sehingga RUPS dengan media teknologi ini tidak keseluruhannya berjalan sebagaimana yang diharapkan. Seperti misalnya kewajiban dibuatnya risalah rapat bagi setiap RUPS dengan cara telekonferensi belum dibuat, sistem teknologi sudah mengalami gangguan.

\subsection{Rumusan Masalah}

Berdasarkan penjabaran latar belakang tersebut di atas, maka dapat dirumuskan permasalahan sebagai berikut:

1. Bagaimanakah

pengaturan penyelenggaraan RUPS dengan telekonferensi melalui online system pada suatu perusahaan yang berbentuk PT?

2. Bagaimanakah kedudukan pemegang saham dalam RUPS dengan sistem telekonferensi terkait jaringan 
bermasalah (down) dalam perspektif cyber law?

\subsection{Tujuan Penelitian}

1. Bertujuan untuk mengetahui dan menganalisis pengaturan mengenai penyelenggaraan RUPS dalam perseroan terkait dengan telekonferensi melalui online system

2. Bertujuan untuk mengetahui dan menganalisis kedudukan pemegang saham dalam RUPS dengan sistem telekonferensi ketika jaringan bermasalah (down) dalam perspektif cyber law.

\subsection{METODE PENELITIAN}

Metode yang digunakan dalam penelitian iniadalah metode penelitian hukum normatif, dengan pendekatan perundangundangan(statuteapproach)serta pendekatan konsep (conceptual approach). Dalam penelitian ini bahan hukum yang diateliti meliputi: Undang-Undang No. 40 Tahun 2007 tentang Perseroan Terbatas (UUPT), Undang-Undang Nomor 11 Tahun 2008 tentang Informasi dan Transaksi Elektronik (UUITE), Peraturan Pemerintah No. 82 Tahun 2012 tentang Penyelenggaraan Sistem dan Transaksi Elektronik (PP 82/2012) serta Undang-Undang No. 2 Tahun 2014 tentang Perubahan atas Undang-Undang No. 30 Tahun 2004 tentang Jabatan Notaris (UUJN). Bahan hukum sekunder dalam penelitian ini adalah terdiri dari berbagai buku, literatur, artikel dan bahan tertulis lainnya yang pada dasarnya berusaha memberikan penjelasan bahan hukum primer. Analisis dilakukan secara deskriftif kualitatif.
II. HASIL DAN PEMBAHASAN

2.1 Pengaturan Mengenai Penyelenggaraan RUPS dalam Perseroan Terkait dengan Telekonferensi Melalui Online System

Berdasarkan ketentuan Pasal 1 angka (2) UUPT, organ perseroan terdiri dari tiga yaitu Rapat Umum Pemegang Saham (RUPS), Direksi dan Dewan Komisaris. Masing-masing organ dalam perseroan tersebut memiliki tugas dan kewenangannya tersendiri yang sudah ditentukan dalam UUPT. Kewenangan yang dimiliki RUPS relative banyak salah satunya adalah kewenangan perubahan anggaran dasar ditetapkan oleh RUPS berdasarkan Pasal 19 ayat (1) UUPT. Dalam UUPT, pengaturan khusus mengenai RUPS dapat ditemukan dalam Bab VI ketentuan Pasal 75 hingga Pasal 91. RUPS ada dua jenis yaitu RUPS tahunan $^{8}$ dan RUPS lainnya.

RUPS lainnya ini dalam praktik sering juga dikenal sebagai RUPS luar biasa. Dalam bahasa inggrisnya yakni extraordinary general meeting. Pelaksanaan dari RUPS lainnya ini berdasarkan ketentuan Pasal 78 ayat (4) UUPT dapat dilaksanakan setiap waktu sesuai dengan kebutuhan untuk kepentingan perseroan. Jika terdapat suatu permasalahan yang timbul mendadak dalam perseroan dan segera membutuhkan keputusan. ${ }^{9}$ Tata cara permohonan RUPS diatur dalam Pasal 79 UUPT.

Handri Raharjo, Op.Cit, h. 94.

Hukum perseroan terbatas, Rapat Umum Pemegang Saham Luar Biasa, diakses pada http://www. hukumperseroanterbatas.com/tag/rups/, pada tanggal 25 Oktober 2014 
Pada dasarnya RUPS dilakukan dengan cara konvensional yaitu semua pemegang saham dalam suatu perseroan datang berkumpul secara fisik pada suatu tempat yang telah ditentukan. Berdasarkan ketentuan dalam Pasal 76 ayat (1) UUPT, diketahui bahwa di tempat kedudukan perseroan atau ditempat perseroanmelakukan kegiatan usahanya yang utama sebagaimana ditentukan dalm anggaran dasar RUPS. Lebih lanjut ayat 3 dari Pasal 76 UUPT menentukan bahwa tempat RUPS (bagi perseroan atau perseroan terbuka (Pasal 76 ayat (2) UUPT) haruslah terletak di wilayah negara Republik Indonesia. RUPS tersebut pada dasarnya dapat diadakan dimanapun dengan memeperhatikan ketentuan yang dimaksud oleh Pasal 76 ayat (3) UUPT jika semua pemegang saham hadir dan/atau diwakili dan semua pemegang saham menyetujui diadakannya RUPS dengan agenda tertentu dalam RUPS (Pasal 76 ayat (4) UUPT). Pasal 76 ayat (5) lebih lanjut menegaskan bahwa RUPS sebagaimana dimaksud pada ayat (4) tersebut dapat mengambil keputusan jika suara bulat telah menyetujui keputusan tersebut.

Sebagaimana telah dikemukakan sebelumnyabahwaRUPS jugadimungkinkan dilaksanakan dengan mempergunakan kecanggihan teknologi dan mempergunakan online system seperti misalnya telekonferensi berdasarkan Pasal 77 (1) UUPT yang mengatur Selain penyelenggaraan RUPS sebagaimana dimaksud dalam Pasal 76, RUPS dapat juga dilakukan melalui media telekonferensi, video konferensi, atau sarana media elektronik lainnya yang memungkinkan semua peserta RUPS saling melihat dan mendengar secara langsung serta berpartisipasi dalam rapat. Juga diatur lebih lanjut bahwa Setiap penyelenggaraan RUPS sebagaimana dimaksud pada ayat (1) harus dibuatkan risalah rapat yang disetujui dan ditandatangani oleh semua peserta RUPS (Pasal 77 Ayat 4 UUPT). Berkaitan dengan persyaratan kuorum juga berkaitan dengan ketentuan Pasal 86, Pasal 88 maupun Pasal 89 UUPT.

Terkait dengan penyelenggaran RUPS dengan media telekonferensi, berdasarkan Pasal 77 ayat (4) UUPT maka setiap penyelenggaraan RUPS tersebut wajib dibuatkan risalah rapat yang disetujui dan ditandatangani oleh semua peserta RUPS. Adapun berdasarkan penjelasan pasal tersebut diketahui bahwa yang dimaksud dengan "disetujui dan ditandatangani" adalah disetujui dan ditandatangani secara fisik atau secara elektronik.

Konsepteleconference dapat dijelaskan sebagai pertemuan yang menggunakan basis elektronik secara langsung (live) di antara dua atau lebih partisipan manusia atau mesin yang dihubungkan dengan suatu sistem telekomunikasi yang biasanya berupa saluran telepon. ${ }^{10}$ Terdapat dua jenis telekonferensi yakni: menggunakan telekonferensi audio dan telekonferensi video Dengan mengacu pada ketentuan Pasal 77 ayat (1) UUPT, maka indikasinya adalah media telekonferensi yang dapat dipergunakan untuk menyelenggarakan

10 Telekonferensi, diakses pada http://id.wikipidea.org/ wiki/Telekonferensi pada tanggal 26 Oktober 2014. 
RUPS sebagaimana diperkenankan UUPT merupakan telekonferensi dengan video (telekonferensi video/video teleconference). Hal ini karena Pasal 77 ayat (1) UUPT mempersyaratkan bahwa media tersebut haruslah memungkinkan semua peserta RUPS tidak hanya saling melihat tapi juga mendengar secara langsung serta berpartisipasi dalam rapat melalui kata "dan" dalampasalnyayakni “memungkinkan semua pesertaRUPSsaling melihat dan mendengar secara langsung serta berpartisipasi dalam rapat." Dengan sistem teknologi komunikasi canggih para pemegang saham dalam RUPS ini dapat secara live melihat dan mendengar satu sama lain serta berpartisipasi dalam rapat. Adapun salah satu kekhasan dari telekonferensi yang mempunyai suatu nuansa hukum adalah rapat dalam RUPS tersebut haruslah mempunyai dampak atau akibat hukum seperti misalnya rapat tersebut diselenggarakan guna memutuskan suatu permasalahan yang dituangkan dalam agenda rapat. ${ }^{11}$

\subsection{Kedudukan Pemegang} Saham dalam RUPS dengan Sistem Telekonferensi Terkait Jaringan Bermasalah (Down) dalam Perspektif Cyber Law

Sebagaimana diatur ketentuan Pasal 77 UUPT bahwa penyelenggaraan RUPS dapat dilakukan dengan mekanisme telekonferensi, yang salah satu tujuannya guna mengatasi masalah jarak dan waktu

\footnotetext{
11 Grace Wahyuni, Ibid, h. 13.
}

ketika melangsungkan RUPS, mekanisme tersebut memungkinkan para pemegang saham dari berbagai lokasi yang berbeda untuk dapat melihat, mendengar dan berpartisipasi dalam RUPS secara langsung sebagaimana dilandasi dalam ketentuan Pasal 77 UUPT.

Berdasarkan ketentuan Pasal 77 ayat (4) diketahui bahwa dalam pelaksanaan RUPS dengan media telekonferensi ini, i harus dibuatkan risalah rapat yang disetujui dan ditandatangani oleh semua peserta RUPS. Dalam Penjelasan Pasal 77 ayat (4) UUPT diatur bahwa "Yang dimaksud dengan "disetujui dan ditandatangani" adalah disetujui dan ditandatangani secara fisik atau secara elektronik."

Sehubungan dengan ketentuanketentuan yang tercantum dalam Pasal 77 UUPT yang memuat landasan hukum bagi diperbolehkannya RUPS dengan media telekonferensi agar dapat berkomunikasi secara live (misalnya dengan media internet online system), dan khususnya berkaitan dengan Pasal 77 ayat (4) UUPT yang menentukan bahwa pada dasarnya RUPS tersebut diindikasikan sah asalkan salah satu syaratnya dibuatkan risalah rapat yang disetujui dan ditandatangani oleh semua peserta RUPS baik secara fisik maupun elektronik, maka penting untuk mengetahui ketentuan yang tercantum dalam UUITE dan PP 82/2012 terkait tanda tangan elektroniknya.

Dalam UUITE definisi yang diberikan mengenai tanda tangan elektronik dapat ditemukan dalam ketentuan Pasal 1 
angka (12), yaitu:

"Tanda Tangan Elektronik adalah tanda tangan yang terdiri atas Informasi Elektronikyang dilekatkan, terasosiasi atau terkait dengan Informasi Elektronik lainnya yang digunakan sebagai alat verifikasi dan autentikasi."

Sejalan dengan definisi tersebut, PP 82/2012 sebagai peraturan pelaksana beberapa ketentuan dalam UUITE juga memberikan definisi yang serupa mengenai tanda tangan elektronik pada Pasal 1 angka (19). Adapun berdasarkan Pasal 52 ayat (1) PP 82/2012, tanda tangan elektronik ini mempunyai dua fungsi yaitu sebagai alat autentikasi dan verifikasi atas identitas penanda tangan dan keutuhan dan keautentikan informasi elektronik.

Dengan adanya penjelasan yang diberikan oleh Pasal 77 ayat (4) UUPT dimana keharusan membuat risalah RUPS telekonferensi wajib disetujui dan ditandatangani oleh semua peserta RUPS yang dapat dilakukan melalui tanda tangan elektronik, dapat dikatakan hal tersebut sejalan dengan Pasal 11 ayat (1) UUITE yang pada dasarnya mengemukakan bahwa tanda tangan elektronik memiliki kekuatan dan akibat hukum yang sah dengan syarat memenuhi persyaratan tertentu.

Sesuai dengan ketentuan Pasal 11 ayat (2) UUITE, maka ketentuan sebagaimana diatur dalam Pasal 11 ayat (1) juga dapat ditemukan secara serupa dalam Pasal 53 ayat (2) PP $82 / 2012$. Ketentuan mengenai tanda tangan elektronik dalam PP 82/2012 ini diatur secara lebih detail daripada UUITE dalam Bab V PP 82/2012 yang berjudul Tanda Tangan Elektronik yang dimulai dari ketentuan Pasal 52 hingga 58.

Tidak dipungkiri lagi dengan berkembangnya kecanggihan teknologi dewasa ini telah menyebabkan secara pasti banyak pergeseran perbuatan hukum secara konvensial menjadi modern seperti misalnya RUPS yang tidak hanya dapat diselenggarakan secara konvensional tapi kini bisa juga dengan media telekonferensi dengan bantuan perangkat komputer atau laptop dengan jaringan internetnya yang memungkinkan para pemegang saham berjauhan lokasi dapat secara langsung melihat dan mendengar serta berpartisipasi dalam rapat. Berdasarkan Pasal 1 angka (2) UUITE serta Pasal 1 angka (2) PP 82/2012, diketahui bahwa transaksi elektronik pada dasarnya adalah perbuatan hukum yang dilakukan dengan menggunakan komputer, jaringan komputer dan/atau media elektronik lainnya. Transaksi elektronik tersebut juga dapat diartikan sebagai suatu kegiatan bertukar informasi yang menggunakan komunikasi elektronik yang bertujuan guna melaksanakan suatu perbuatan hukum tertentu. ${ }^{12}$ Jaminan keamanan terhadap suatu komunikasi tersebut sangatlah diperlukan dan mempunyai syarat: ${ }^{13}$

\footnotetext{
Edmon Makarim, Op.cit, h. 45. Ibid, h. 46.
} 
(UDAYANA MASTER LAW JOURNAL)

1. Authenticity yaitu keauntentikan pesan;

2. Authorization yaitu otorisasi kewenangan;

3. Confidentiality yaitu kerahasiaan pesan yang dikomunikasikan;

4. Integrity yaitu keutuhan pesan yang dikomunikasikan;

5. Availability yaitu ketersediannya; dan

6. Non-repudiation yaitu tidak dapat disangkal.

Electronic signatures atau electronic authentication merupakanmetodeautentikasi secara elektronik yang memfasilitasi kesemua syarat tersebut. ${ }^{14}$

Dengan mencermati ketentuan PasalPasal tersebut di berkaitan dengan kedudukan pemegang saham dalam RUPS dengan sistem telekonferensi,dapat dikemukakan bahwa pihak pemegang saham akan memiliki kedudukan hukum sah sebagai pihak yang memiliki hak suara sepanjang dapat membuktikan bahwa yang bersangkutan telah dihitung keikutsertaannya, dan harus dibuatkan risalah yang disetujui dan ditandatangani oleh semua peserta RUPS sebagaimana diatur dalam ketentuan Pasal 77 Ayat (3( dan (4) UUPT. Dalam konteks Cyberlaw, khususnya berdasarkan UUITE dan PP 82/2012, tentu saja penghitungan keikutsertaannya sertatandatangan dilakukan melalui media teleconference. Dalam hal ini ini pemegang saham yang berada ditempat yang terpisah dapat mengirimkan tanda tangannya secara elektronik setelah

14 Ibid. berkomunikasi dengan teleconference saling melihat dan mendengar antara pemegang saham yang berada di tempat terpisah dengan tempat dimana dipusatkannya penyelenggaraan RUPS tersebut.

Sarana teknologi internet tidak selamanya dapat diakses dengan baik dari seluruh penjuru wilayah, dalamkenyataannya terkadang, bahkan seringkali pada tempattempat yang wilayah demografinya berbukitbukit kendalanya seringkali jaringan internet tidak stabil. Dalam kaitannya dengan RUPS dengan menggunakan sarana teleconference bisa ketika RUPS sedang berlangsung jaringan mengalami permasalahan (system down).

Sebagaimana telah dijabarkan dalam Bab II sebelumnya, pada dasarnya yang dimaknai sebagai cyber law adalah seluruh aspek yang memiliki kaitan baik itu dengan subjek hukum atau orang perorangan yang basisnya menggunakan dan memanfaatkan teknologi yang semakin canggih yakni berupa internet yang mulainya pada saat online dan memasuki dunia maya. Konsep ini sesuai dengan yang telah dijelaskan sebelumnya dimana telekonferensi sebagai sarana RUPS dalam kajian ini adalah dengan menggunakan jaringan internet dimana secara online system dengan menggunakan aplikasi (misalnya skype) mempermudah para pemegang saham yang lokasi berjauhan untuk dapat secara langsung (live) melihat dan mendengar serta berpartisipasi dalam suatu rapat perseroan tersebut.

Kecanggihan teknologi seperti misalnya penyelenggaraan RUPS 
suatu perseroan dengan telekonferensi menggunakan internet (online system) tidak dapat dipungkiri mampu menghemat dan mempermudah para pemegang saham dengan lokasi berjauhan mengambil keputusan. Akan tetapi, secanggih-canggihnya teknologi yang diciptakan manusia pasti mempunyai celah kelemahan. Seperti misalnya dalam praktek penyelenggaraan RUPS dengan telekonferensi menggunakan internet bisa saja terjadi suatu keadaan dimana jaringannya tersebut bermasalah atau down. Dengan adanya kelemahan dari teknologi tersebut maka bisa saja muncul dalam praktek RUPS dengan telekonferensi ini yang seharusnya dibuatkan risalah rapat yang disetujui dan ditandatangani oleh semua peserta RUPS ternyata belum sempat ditandatangani secara elektronik (dan misalnya belum terkirim melalui email oleh semua peserta RUPS akibat jaringan down.

Terkait pemasalahan yang menyangkut penyelenggaraan RUPS dengan cara telekonferensi dan telekonferensi tersebut terganggu misalnya risalah rapatnya belum sempat ditandatangani secara fisik atau elektronik oleh semua peserta RUPS sehingga muncul pertanyaan bagaimanakah kedudukan pemegang saham dalam RUPS tersebut jika adanya jaringan bermasalah (down), UUPT tidak mengatur hal tersebut, dalam konteks ini dapat dikemukakan terjadi kekosongan hukum. Dengan mencermati ketentuan Pasal 77 UUPT dapat diketahui UUPT hanya mengakomodir perkembangan zaman dan kecanggihan teknologi yang ada dengan memungkinkannya pelaksanaan
RUPS dengan telekonferensi akan tetapi tidak mengatur ketentuan back up jika seandainya ketentuan Pasal 77 ayat (4) yang merupakan salah satu pengindikasian suatu RUPS telekonferensi sah (yaitu harus disetujui dan ditandatangani (baik secara fisik atau dapat juga secara elektronik) oleh semua peserta RUPS) belumlah terpenuhi. Melalui hal tersebut dapatlah dikemukakan bahwa telah ditemukan adanya suatu norma kosong terkait permasalahan ini. Dalam prakteknya dapat timbul suatu keraguan mengenai apakah RUPS telekonferensi yang sudah disetujui oleh semua peserta RUPS dengan media teleconference pada awalnya , serta sudah ada penandatanganan yang dikirim secara elektronik, tetapi pada saat akhir pembuatan risalah RUPS belum sempat ditandatangani karena jaringan internet atau tidak ada akses internet yang dapat menghubungkan antara pemegang saham yang berada di tempat terpisah dengan pusat penyelenggaraan RUPS.

Dengan adanya norma kosong terkait permasalahan di atas, penelitian ini akan coba mengkaji hal tersebut dengan ketentuan lainnya yang dapat ditemukan baik itu dalam UUPT maupun UUJN guna mengindikasikan dan mencari solusi atas permasalahan tersebut. Indikasi pertama yang akan dipergunakan guna mencari jalan atas permasalahan tersebut adalah dengan menghubungkan ketentuan Pasal 77 UUPT yang spesifik mengatur mengenai RUPS telekeonferensi dengan ketentuan UUPT lainnya yang mengatur ketentuan terkait kewajiban pembuatan risalah RUPS 
sebagaimana diatur dalam Pasal 90 UUPT yaitu:

“(1) Setiap penyelenggaraan RUPS, risalah RUPS wajib dibuat dan ditandatangani oleh ketua rapat dan paling sedikit 1 (satu) orang pemegang saham yang ditunjuk dari dan oleh peserta RUPS.

(2) Tanda tangan sebagaimana dimaksud pada ayat (1) tidak disyaratkan apabila risalah RUPS tersebut dibuat dengan akta notaris."

Berdasarkan ketentuan Pasal 90 ayat (2) UUPT tersebut pada dasarnya dapat dikemukakan bahwa RUPS yang diselenggarakan pada umumnya tidak mempermasalahkan apabila kewajiban pembuatan risalah RUPS bagi setiap RUPS tidak ditandatangani sekalipun oleh ketua rapat dan paling sedikit 1 (satu) orang pemegang saham yang ditunjuk dari dan oleh peserta RUPS (sebagaimana ditentukan dalam ayat (1)) asalkan persyaratan berupa risalah RUPS tersebut dibuat dengan akta notaris dapat terpenuhi. Berarti dalam penyelenggaraan RUPS dalam konteks konvensional, kedudukan dan keberadaan pemegang saham tetap diperhitungkan sebagai subjek yang secara sah memiliki hak suara meskipun tidak membubuhkan tanda tangan asalkan risalah RUPS tersebut dibuat dengan akta notaris, serta hal tersebut tidak mempengaruhi keabsahan pelaksaan RUPS.

Sehubungan dengan adanya norma kosong, maka secara metodologis, teknik analisis bahan hukum yang dapat digunakan adalah analis dengan teknik konstruksi, yaitu pembentukan konstruksi yuridis dengan melakukan analogi dan pembalikan proposisi (acontrario). ${ }^{15}$ Oleh karena itu, jika ketentuan Pasal 90 ayat (2) UUPT dianalogikan dan dipergunakan guna mengatasi ketentuan Pasal 77 ayat (4) UUPT (mengenai kewajiban pembuatan risalah rapat yang tidak hanya disetujui tapi juga harus ditandatangani (entah fisik atau elektronik) oleh semua peserta RUPS) dalam kaitannya dengan jaringan internetnya down maka dapat diindikasikan tidak ada masalah jika para peserta RUPS dalam RUPS telekonferensi tersebut belum sempat menandatangani risalah rapat itu (baik secara atau elektronik) dan oleh karenanya melalui tehnik analogi hukum dapat dikemukakan bahwa kedudukan pemegang saham yang berada di tempat terpisah dan belum sempat membubuhkan ataupun mengirimkan tandatangan baik secara lisan maupun elektronik terkait risalah RUPS, tetap berkedudukan sebagai subjeek hukum yang sah menghadiri RUPS dan dianggap memiliki hak suara dalam menentukan risalah RUPS sepanjang Risalah RUPS dilakukan dengan Akta Notaris. Dengan kata lain, RUPS tersebut tetaplah sah asalkan persyaratan risalah RUPS tersebut dibuat dengan akta notaris terpenuhi sebagaimana ditentukan Pasal 90 ayat (2) UUPT.

Indikasi kedua yang dapat dipergunakan untuk mencari solusi atas pemasalahanjaringan down sedangkan dalam

15 Program Studi Magister (S2) Ilmu Hukum Program Pascasarjana Universitas Udayana Denpasar, 2013, Pedoman Penulisan Usulan Penelitian Tesis dan Penulisan Tesis Program Studi Magister (S2) Ilmu Hukum, Denpasar, h.32. 
RUPS telekonferensi misalnya semua peserta rapat belum sempat menandatangani risalah rapat sebagaimana disyaratkan Pasal 77 ayat (4) UUPT adalah dengan mencoba melihat kepada UUJN. Berdasarkan ketentuan Pasal 1 angka (7) UUJN yang dimaksud dengan akta notaris adalah akta otentik yang dibuat oleh atau di hadapan Notaris menurut bentuk dan tata cara yang ditetapkan dalam UUJN. Terdapat dua macam atau golongan akta notaris yakni: ${ }^{16}$

1. Akta relaas/Akta pejabat/Akta yang dibuat oleh notaris

Akta yang dibuat notaris yang berisikan uraian dari notaris suatu tindakan yang dilakukan atas suatu keadaan yang dilihat atau disaksikan oleh notaris misalnya akta berita acara/risalah RUPS suatu perseroan, akta pencatatan bundel dan lainnya.

2. Akta partij/Akta yang dibuat di hadapan notaris

Akta yang dibuat di hadapan notaris yang berisikan uraian dari apa yang diceritakan atau diterangkan oleh para pihak yang menghadap kepada notaris, contohnya adalah perjanjian kredit.

Berdasarkan hal tersebut dapat dikemukakan bahwa akta relaas adalah jenis akta dari RUPS dengan cara telekonferensi dimana keterangan notaris dalam wujud akta RUPS telekonferensi ini keabsahannya dapat dipastikan meskipun para pihak tidak sempat memberikan tanda tangannya ${ }^{17}$ (misalnya

\footnotetext{
16 Alfi Renata, Akta Notaris, diakses pada http://www. hukumonline.com/klinik/detail/cl1996/akta-notaris.

17 Grace Wahyuni, Op.cit, h. 35
}

secara elektronik) pada akta karena jaringan internet sedang down namun akta notaris yang membuat berita acaranya tersebutlah yang nantinya akan menjadi suatu akta yang otentik dan mempunyai pembuktian sempurna. Hal ini karena akta relaas adalah akta yang dibuat oleh notaris sehingga berita acara dalam RUPS telekonferensi yang termasuk dalam jenis akta ini mempunyai celah dimana para pihak dimungkinkan untuk tidak menandatanganinya asalkan kewajiban ditandatangani oleh notaris sebgai pejabat yang membuat akta tersebut terpenuhi. ${ }^{18}$ Hal tersebut dapat dipergunakan guna mengindikasikan bahwa sebenarnya RUPS dengan media telekonferensi yang menghadapi hambatan dimana jaringannya down dan semua peserta rapat belum sempat menandatangani risalah rapatnya (baik secara fisik ataupun elektronik) menjadi tidak bermasalah dan sah asalkan dibuatkan akta notarisnya yang dalam hal ini merupakan bagian dari akta relaas_yang bahkan sesungguhnya tidak masalah jika tidak ditandatangani oleh para pihak asalkan syarat wajib ditandatangani oleh notaris sebagai pejabat pembuat akta itu terpenuhi.

\section{SIMPULAN \& SARAN}

\section{Simpulan}

Berdasarkan penjabaran yang telah diuraikan dalam bab-bab sebelumnya dapat dikemukakan simpulan sebagai berikut:

1. Pengaturan mengenai penyelenggaraan RUPS dalam perseroan terkait dengan

\footnotetext{
$18 \quad$ Ibid.
} 
telekonferensi melalui online system diatur dalam ketentuan Pasal 77 ayat (1) sampai (4) UUPT yang pada intinya mengatur bahwa RUPS dengan telekonferensi dapat dilakukan, yang mana melalui mekanisme telekonferensi memungkinkan semua peserta rapat untuk saling melihat dan mendengar satu sama lain serta berpartisipasi dalam rapat.

2. Kedudukan pemegang saham dalam RUPS dengan mekanisme telekonferensi yang mengalami jaringan bermasalah (down), tetap diakui hak suaranya sepanjang dibuat dengan risalah RUPS yang dibuat dengan akta notaris.

\section{Saran}

Guna menciptakan dan menjamin adanya kepastian hukum terutama bagi pelaku bisnis dalam kegiatan korporasi dapat diajukan saran sebagai berikut:

1. Diharapkan ke depannya pemerintah beserta badan legislative dapat membuat ketentuan yang secara lebih detail lagi mengatur mengenai penyelenggaraan RUPS dengan media telekonferensi. Hal ini karena meskipun perkembangan teknologi amatlah pesat dan canggih, namun dalam prakteknya pasti terdapat celah kelemahan yang juga perlu untuk diperhitungkan dan diatur dalam ketentuan-ketentuan peraturan perundang-undangan untuk mengatasinya agar tidak hanya mengakomodir perbuatan hukum baru sebagai akibat pesatnya teknologi saja, akan tetapijuga mengkonstruksi aturan hukum berkaitan dengan kelemahan dari sitem teknologi informasi.

2. Ketentuan Pasal 90 UUPT kiranya relevan diterapkanmaupundinormakan dalam mengkonstruksi norma baru berkaitan dengan RUPS yang diselenggarakan dengan mekanisme teleconference, khususnya ketika jaringan internet bermasalah (system down).

\section{DAFTAR PUSTAKA}

\section{Buku:}

Bambang Sunggono. 2001. Metodologi Penelitian Hukum. PT Raja Grafindo Persada. Jakarta

Edmon Makarim. 2012. Notaris \& Transaksi Elektronik (Kajian Hukum tentang Cybernotary atau Electronic Notary). PT. Rajagrafindo Persada. Jakarta Gunawan Widjaja(1).2008.SeriPemahaman Perseroan Terbatas: 150 Pertanyaan Tentang Perseroan Terbatas. Forum Sahabat

Gunawan Widjaja (2). 2008. Risiko Hukum Sebagai Direksi. Komisaris \& Pemilik $P T$. Forum Sahabat

Handri Raharjo. 2009. Hukum Perusahaan.

Penerbit Pusataka Yustisia.

Yogyakarta

Jamin Ginting. 2007. Hukum Perseroan Terbatas (UU No. 40 Tahun 2007). PT Citra Aditya Bakti. Bandung 
Johnny Ibrahim. 2007. Teori \& Metodologi Penelitian Hukum Normatif. Bayumedia Publishing. Malang

Munir Fuady. 2005. Perlindungan Pemegang Saham Minoritas. CV Utomo. Bandung

Program Studi Magister (S2) Ilmu Hukum Program Pascasarjana Universitas Udayana Denpasar. 2013. Pedoman Penulisan Usulan Penelitian Tesis dan Penulisan Tesis Program Studi Magister (S2) Ilmu Hukum. Denpasar

Soerjono Soekanto dan Sri Mamudji. 2007. Penelitian Hukum Normatif: Suatu Tinjauan Singkat. PT RajaGrafindo Persada. Jakarta

\section{Internet:}

Alfi Renata. Akta Notaris. Diakses pada http:/www.hukumonline.com/klinik/ detail/cl1969/akta-notaris pada tanggal 27 Oktober 2014.

Apa yang Dimaksud dengan Jaringan dalam Kondisi Down. Diakses pada https:// id.answer.yahoo.com/question/index?qid=2 0111220222647AAUWsQy pada tanggal 27 Oktober 2014

Grace Wahyuni. Diakses pada http//www. google.co.id/url? $\mathrm{sa}=\quad=\mathrm{t} \& \mathrm{rct}=\mathrm{j} \& \mathrm{q}=\&$ esrc $=$ $\mathrm{s} \&$ source $=$ web\&cd $=3 \& \mathrm{cad}=$ rja\&uact $=8 \&$ v e d $=0$ C C o Q F j A C \& u r l = h t t p \% 3 A\%2F\%2Flib.ui.ac.id\%2Ffile \% 3 Ffile \% 3 D digital \% 2 F 128943 T\%252026707-Keabsahan\%2520tandaAnalisis.pdf\&ei=andLVI_QFIn f 8 A X u 64 C A B A \& u s g = A F Q j C N H Yqh 91 c Im Vk L R 31 P i 01 fub n F0pew\&bvm=bv.77880786,d.dGcpada tanggal 25 Oktober 2014

Hukum Perseroan Terbatas. Rapat Umum Pemegang Saham Luar Biasa. Diakses pada http://www.hukumperseroanter batas.com/ tag/rups/ pada tanggal 25 Oktober 2014

Jaringan Internet, diakses pada http://www. slideshare.net/finiy uliani/dasar-dasarsistem-jaringan-internet-dan-intranet11884708 pada tanggal 27 Oktober 2014 Kamus Besar Bahasa Indonesia, diakses pada http://kbbi.web.id/tanda+tangan pada tanggal 26 Oktober 2014

Perkembangan Cyber Law di Indonesia. Diakses pada http://cipluk2bsi.wordpress.co $\mathrm{m}$ /perkembangan-cyber-law-di-indonesia/ pada tanggal 24 Oktober 2014

Squal Adityo. Cyber Law. Diakses pada http://www.academia.edu/7069 $627 /$

Cyberlaw pada tanggal 24 Oktober 2014 